\title{
Effect of planting patterns of sunflower on yield and extinction coefficient
}

\author{
Mohammad J. ZAREA*, Amir GHALAVAND, Jahanfar DANESHIAN \\ Department of Agronomy, Tarbiat modares university (TMU), PO Box 14115-336, Tehran, Iran
}

(Accepted 12 July 2005)

\begin{abstract}
We studied the effect of different planting patterns and density of sunflower on yield and on extinction coefficient. The experiment was conducted in the field at the Seed and Plant Improvement Institute, Karaj, Iran on a loamy clay. Planting patterns included wide rows, conventional rows, twin rectangular rows and twin zigzag rows. Populations of plants were at 3 levels including 6,8 and 10 plants per square meter. The results show that different planting patterns sometimes produced higher yield, but not always. Furthermore, equidistant plant distribution at equal plant densities produced a higher radiation interception and extinction coefficient. Moreover, when row spacing was reduced, grain yield increased. The greatest increase in radiation interception and in the extinction coefficient in response to planting patterns and plant densities was observed in twin zigzag rows of 8 plants $\mathrm{m}^{-2}$. Twin zigzag rows of 8 plants $\mathrm{m}^{-2}$ and conventional rows of 8 plants $\mathrm{m}^{-2}$ produced the highest yield.
\end{abstract}

extinction coefficient / planting patterns / sunflower

\section{INTRODUCTION}

In Iran, approximately $80 \%$ of oilseed for human food is imported, so increasing sunflower production is an option to reduce this deficit. Adequate plant density and a planting pattern with optimum spatial arrangement (equidistant is superior) are important cultural factors that increase radiation interception (RI) and yield production. Decreasing row spacing at equal plant densities decreases plant-to-plant competition for radiation interception (RI) and biomass production (Bullock et al., 1988; Andrade et al., 2002) but the results of planting patterns on the cropping produced variable conclusions; some indicated that a clear difference in patterns caused high yield (Robinson et al., 1980; Ikeda and Sato, 1992), and others indicated that clear differences in yield were not found (Wiggans 1939; Wilocox, 1974; Nishiiri, 1976). Sunflower yield (Andrade et al., 2002) and soybean yield (Duncan, 1986; Ikeda and Sato, 1992) increased in response to narrow rows. From several plant population studies (Goubbels and Dedio, 1990), it was shown that a population of 7.4 plants $\mathrm{m}^{-2}$ produced higher yield in sunflower than 5.5 plants $\mathrm{m}^{-2}$; with an increase in population to 14.8 plants $\mathrm{m}^{-2}$, there is no effect on changing yield. When row spacing is reduced light interception increases. There are times during the crop cycle that are most critical for yield determination. These times comprise the period bracketing flowering in sunflower (Chimenti and Hall, 1992, Connor and Sadras, 1992; Cantagallo et al., 1997). Therefore, the response of grain yield to narrow rows can be analyzed in terms of the effect on the amount of radiation interception (RI) at the critical periods for kernel set. Higher crop growth rates during these periods may not be achieved with wide rows (Andrade et al., 2002). Increase in light interception by reducing row spacing has been reported for corn (Egharevba, 1975; Flenet et al., 1996; Andrade et al., 2002), sorghum (Clegg et al., 1974; Graham et al., 1988; Muchow et al., 1990; Flenet et al., 1996), soybean (Mason et al., 1980; Boared et al., 1990; Andrade et al., 2002) and sunflower (Flenet et al., 1996; Andrade et al., 2002). Greater light interception often increases yield (Alessi et al., 1977; Karlen and Camp, 1985; Parvez et al., 1989; MacGowan et al., 1991). Sunflower yield increase in response to narrow rows is closely related to the improvement in light interception during the critical period for grain set (Andrade et al., 2002). Maize biomass at maturity has a linear relationship with cumulative intercepted photosynthetically active radiation (Edwards et al., 2005). Light interception and leaf area are criteria to maintain optimum soybean yield (Board, 2004). Flenet et al. (1996) showed that the stage of development $\times$ row spacing interaction did not significantly alter $\mathrm{k}$ during the period of measurement in corn, sorghum, soybean and sunflower. The k-values calculated were 0.4 for corn (Muchow et al., 1990), 0.45 for soybean (Kiniry et al., 1992), and 0.8 (Steer et al., 1993), 0.6 (Sinclair, 1986) and 0.9 (Kiniry et al., 1992) for sunflower. Murphy et al. (1996) showed that 50 -cm-row corn gave 16 to $21 \%$ greater suppression of late-emerging weeds than 75-cm-row corn and higher

* Corresponding author: zarea@modares.ac.ir 
Table I. Treatments of planting patterns, number of rows sowing, planting densities (plants $\mathrm{m}^{-2}$ ), distance between of plant on rows sowing $(\mathrm{cm})$ and between rows $(\mathrm{cm})$.

\begin{tabular}{lcccc}
\hline $\begin{array}{l}\text { Between } \\
\text { rows } \\
(\mathrm{cm})\end{array}$ & $\begin{array}{c}\text { Distance } \\
\text { between plants } \\
\text { in rows sown } \\
(\mathrm{cm})\end{array}$ & $\begin{array}{c}\text { Planting } \\
\text { densities } \\
\left(\text { plants } \mathrm{m}^{-2}\right)\end{array}$ & $\begin{array}{c}\text { Number of } \\
\text { rows } \\
\text { sowing }\end{array}$ & $\begin{array}{c}\text { Planting } \\
\text { patterns }\end{array}$ \\
\hline 75 & 22 & 6 & 1 & \\
75 & 17 & 8 & 1 & Wide row \\
75 & 13 & 10 & 1 & \\
50 & 33 & 6 & 1 & Conventional \\
50 & 25 & 8 & 1 & row \\
50 & 20 & 10 & 1 & Twin \\
75 & 44 & 6 & 2 & rectangular row \\
75 & 33 & 8 & 2 & row \\
75 & 27 & 10 & 2 & 2 \\
75 & 44 & 6 & 2 & Twin zigzag \\
75 & 33 & 8 & 2 & row \\
75 & 26 & 10 & 2 & \\
\hline
\end{tabular}

corn density also gave 30 to $41 \%$ greater suppression of lateemerging weeds than the control corn density, the greater light interception giving about $8 \%$ more light to the silk than a wide row.

\section{MATERIALS AND METHODS}

Hybrid azargol sunflower seeds with semi-dwarf and early maturity (the most popular sunflower in Iran) were handplanted on 6 July 2003 in the field at the Seed and Plant Improvement Institute, Karaj, Iran on loamy clay (about $1323 \mathrm{~m} \mathrm{Alt}, 35^{\circ} 48^{\prime} \mathrm{N}$ Lat). Experimental plots were $21 \mathrm{~m}^{2}$ ( 6 by $3.5 \mathrm{~m}$ ). The sunflower planting date is normally 15 May, but it was planted on 5 July after the wheat harvest. Fertilizer was applied before planting at the rate of $150-100-0 \mathrm{~kg} \mathrm{ha}^{-1}(\mathrm{~N}-$ $\mathrm{P}-\mathrm{K})$ according to soil test recommendations. Weeds were controlled by hand as needed and no problems with diseases or insects occurred. The seeds were sown at a rate of three to four seeds in shallow holes at a depth of $5 \mathrm{~cm}$ and firmly covered. Prior to $\mathrm{V}_{4}$ [V (number) Vegetative Stages (i.e. V-1, V-2, V3 , etc.). These are determined by counting the number of true leaves at least $4 \mathrm{~cm}$ in length, beginning as V-1, V-2, V-3, V4 , etc. (Schneiter and Miller, 1981)] they were thinned to one stand ( $25 \mathrm{~d}$ after emergence). The experimental design was factorial with a complete randomized block arrangement of treatment in 4 replications.

\subsection{Planting patterns and plant densities}

The planting patterns were at 4 levels including wide rows with $75 \mathrm{~cm}$ between the rows $\left(\mathrm{P}_{1}\right)$, conventional rows with $50 \mathrm{~cm}$ between the rows $\left(\mathrm{P}_{2}\right)$, twin rectangular rows with $75 \mathrm{~cm}$ between the rows $\left(\mathrm{P}_{3}\right)$ and twin zigzag rows $\left(\mathrm{P}_{4}\right)$ with $75 \mathrm{~cm}$ between the rows. The population of plants was at 3 levels including 6 plants $\mathrm{m}^{-2}\left(\mathrm{~d}_{1}\right)\left(6\right.$ plants $\mathrm{m}^{-2}$ is the only population for optimal planting dates or early season planting in Karaj), 8 plants $\mathrm{m}^{-2}\left(\mathrm{~d}_{2}\right)$ and 10 plants $\mathrm{m}^{-2}\left(\mathrm{~d}_{3}\right)$ (Tab. I and Fig. 1). Row spacing was not changed in all cases and when densities became too high, the distance between plants in a row was changed.

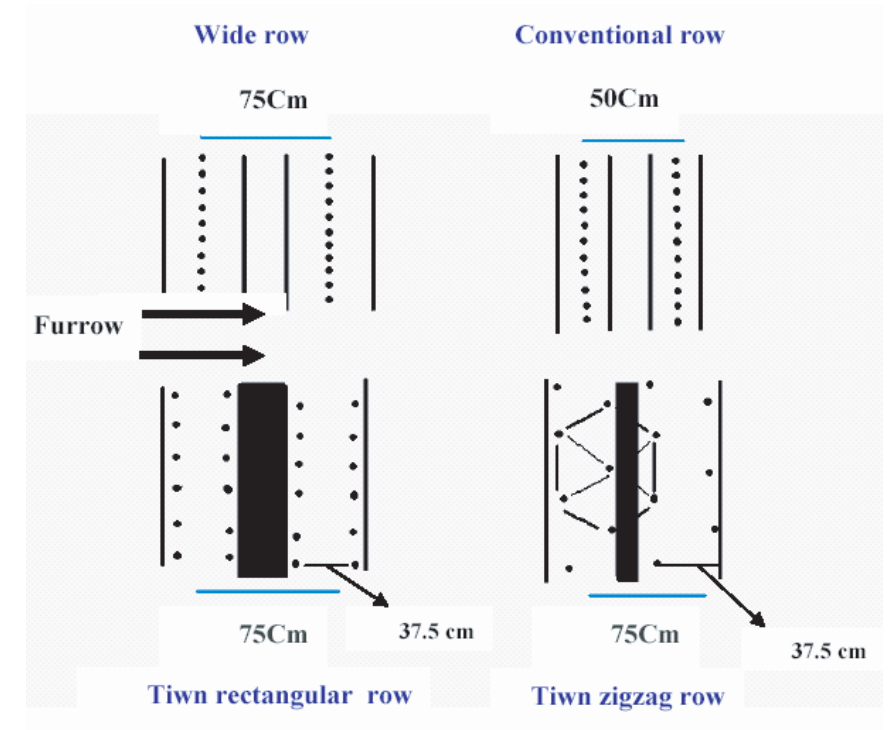

Figure 1. Treatments of planting patterns.

\subsection{Sampling and measurements}

At 25, 35, 45, 55, 65, 75 and $85 \mathrm{~d}$ after planting, 6, 8 and 10 plants were systematically selected from the low $\left(\mathrm{d}_{1}=\right.$ 6 plants $\left.\mathrm{m}^{-2}\right)$, medium $\left(\mathrm{d}_{2}=8\right.$ plants $\left.\mathrm{m}^{-2}\right)$ and high plant $\left(\mathrm{d}_{3}=\right.$ 10 plants $\left.\mathrm{m}^{-2}\right)$ population plots, respectively, for LAI $\left(\mathrm{m}^{2} \mathrm{~m}^{-2}\right)$ and total dry matter $\left(\mathrm{g} \mathrm{m}^{-2}\right)$. Samples were separated into leaves and stem. After leaf area measurement by placing the leaf blades through a leaf area meter (MK2; Delta-T Devices Ltd, Cambridge, UK), plant parts were dried in an oven at $60{ }^{\circ} \mathrm{C}$ to a constant weight. The data obtained were light interception [LI (\%)], extinction coefficient $(\mathrm{K}), \mathrm{LAI}\left(\mathrm{m}^{2} \mathrm{~m}^{-2}\right)$ and TDM $\left(\mathrm{g} \mathrm{m}^{-2}\right)$. 15 measurements were taken above the canopy to determine ambient light and 15 below the rows (an average of 8 measurements made across the row and 7 measurements made parallel to the row). Determinations were taken at $\mathrm{V}_{8}$, close to flowering at $\mathrm{V}_{18}$ and the $\mathrm{R}-1$ growth stages [stage according to Schneiter and Miller (1981)]. A 1- $\mathrm{m}^{2}$ section of the interior rows of each plot was hand-harvested at maturity (a week after R-9) and then the seeds were separated by combine to determine yield and yield components. Seed samples from each plot were dried in an oven at $60{ }^{\circ} \mathrm{C}$, weighed, and seed oil content was determined by Inframatic_8000.

\subsection{Methods of light interception and extinction coefficient}

Radiation interception was calculated by using

$$
\left(1-\mathrm{I}_{\mathrm{t}} / \mathrm{I}_{0}\right) \times 100
$$

where $I_{t}$ is incident PAR (photosynthetically active radiation). Just below the lowest layer of photosynthetically active leaves and $\mathrm{I}_{0}$ is incident PAR at the top of the canopy. The light interception $\left(I_{t}\right.$ and $\left.I_{0}\right)$ was determined with a $1-m$-long LI-COR 
Radiation interception(RI)

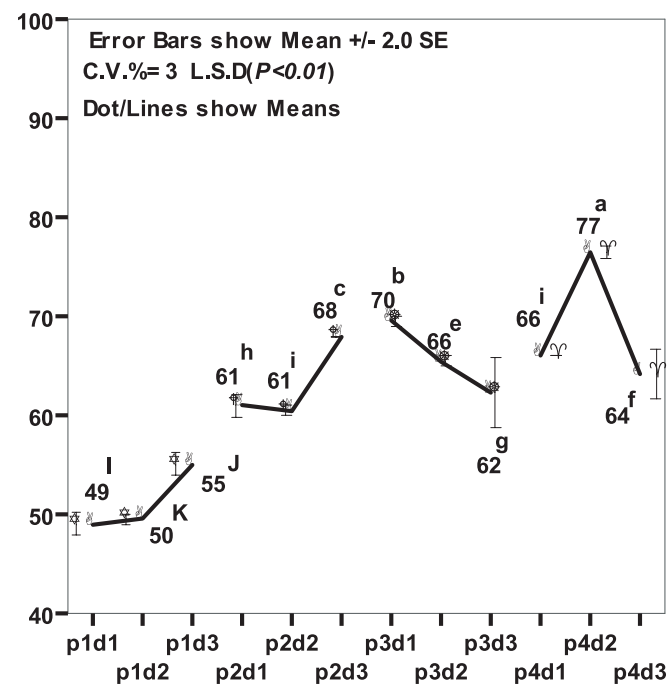

Figure 2. Relationships regarding radiation interception (RI) increase in response to planting patterns and plant densities. $P=$ planting patterns; $P_{1}=$ wide rows, $P_{2}=$ conventional rows, $P_{3}=$ twin rectangular rows, $P_{4}=$ twin zigzag rows. $\mathrm{d}=$ planting densities; $\mathrm{d}_{1}=6$ plants $\mathrm{m}^{-2}$, $\mathrm{d}_{2}=8$ plants $\mathrm{m}^{-2}, \mathrm{~d}_{3}=10$ plants $\mathrm{m}^{-2}$. Means comparison defined by Duncan's range test at the $5 \%$ level.

line Quantum sensor (LI-COR, Lincoln, NE) under clear skies at noon $( \pm 1.5)$.

The extinction coefficient $(\mathrm{K})$ was calculated by

$$
\text { TPAR/PAR }=\exp (-\mathrm{K} \times \mathrm{LAI})
$$

where TPAR and $\mathrm{K}$ represent transmitted PAR and the extinction coefficient, respectively.

\subsection{Irrigation}

The location has a temperate climate with mild, rainy $(250 \mathrm{~mm})$ winters and dry, hot summers. All plots of wide row planting patterns and conventional row planting patterns consisted of nine east-west rows (2 rows were border rows) but all plots of twin rectangular rows and twin zigzag rows consisted of 6 twin rows (all plots of the treatment were $21 \mathrm{~m}^{2}$ ) (Fig. 1). Therefore, in all plots of twin rectangular and twin zigzag arrangements were 7 furrows (every two rows were irrigated by one furrow) while in the other planting patterns it was 10 furrows (each row takes up water from two furrows) (Fig. 1). The amount of inflow of water was the same to all furrows.

\subsection{Statistical analysis}

Analysis of variance was according to SAS with mean separation by LSD.

\section{RESULTS AND DISCUSSION}

\subsection{Light interception and extinction coefficient}

In this experiment the greatest $(P<0.01)$ increases in the radiation interception (RI) and extinction coefficient in
Extinction coeficient(K)

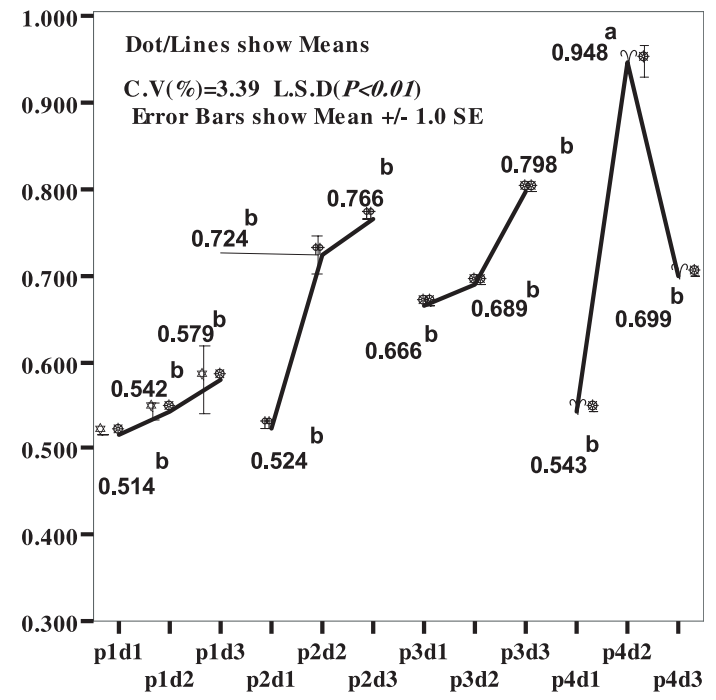

Figure 3. Relationships regarding extinction coefficient $(k)$ increase in response to planting patterns and plant densities. $P=$ planting patterns; $P_{1}=$ wide rows, $P_{2}=$ conventional rows, $P_{3}=$ twin rectangular rows, $P_{4}=$ twin zigzag rows. $\mathrm{d}=$ planting densities; $\mathrm{d}_{1}=6$ plants $\mathrm{m}^{-2}$, $\mathrm{d}_{2}=8$ plants $\mathrm{m}^{-2}, \mathrm{~d}_{3}=10$ plants $\mathrm{m}^{-2}$. Means comparison defined by Duncan's range test at the $5 \%$ level.

response to plant densities and planting patterns were observed in the twin zigzag arrangement with 8 plants $\mathrm{m}^{-2}$ at $\mathrm{R}-1(\mathrm{~K}=$ $0.94, \mathrm{RI}=0.76$ ) (Figs. 2 and 3). Similar results were observed at $V_{8}$ and $V_{18}$ (data not shown). Our results support the results of previous studies for the effect of row spacing on RI and $\mathrm{K}$ (Clegg et al., 1974; Egharevba, 1975; Mason et. al., 1980; Graham et al., 1988; Zaffaroni and Schneiter, 1989; Flenet et al., 1996; Andrade et al., 2002).

LAI during the vegetative period was not significant $(P<$ 0.05 ), except that $45 \mathrm{~d}$ after planting conventional planting patterns $\times 8$ plants $\mathrm{m}^{-2}$ had the highest LAI (Fig. 4). Decreasing row spacing at equal plant densities reduces the leaf area index required to intercept $95 \%$ of the incident radiation due to an increase in the light extinction coefficient (Flenet et al., 1996; Andrade et al., 2002).

LAI during the reproductive period in the twin zigzag arrangement was usually significantly $(P<0.05)$ higher than other planting patterns (Fig. 4).

The twin zigzag arrangement had significantly $(P<0.05)$ higher total dry matter during the growth season (Fig. 4).

\subsection{Yield and yield components}

At the rate of 6 plants $\mathrm{m}^{-2}$ there was no significant difference between planting patterns on thousand seed weight (Tab. II). Although $(P<0.05)$ planting pattern effects did not occur for thousand seed weight, plant densities had a significant effect $(P<0.05)$ (Tab. II). Maximum thousand seed weight was achieved at a plant population of 6 plants $\mathrm{m}^{-2}$ (Tab. II). Planting at the higher rate $\left(8\right.$ and 10 plants $\mathrm{m}^{-2}$ ) resulted in reducing thousand seed weight. Thousand seed weight for the highest rate (10 plants $\mathrm{m}^{-2}$ ) was lower for wide rows and twin rectangular 

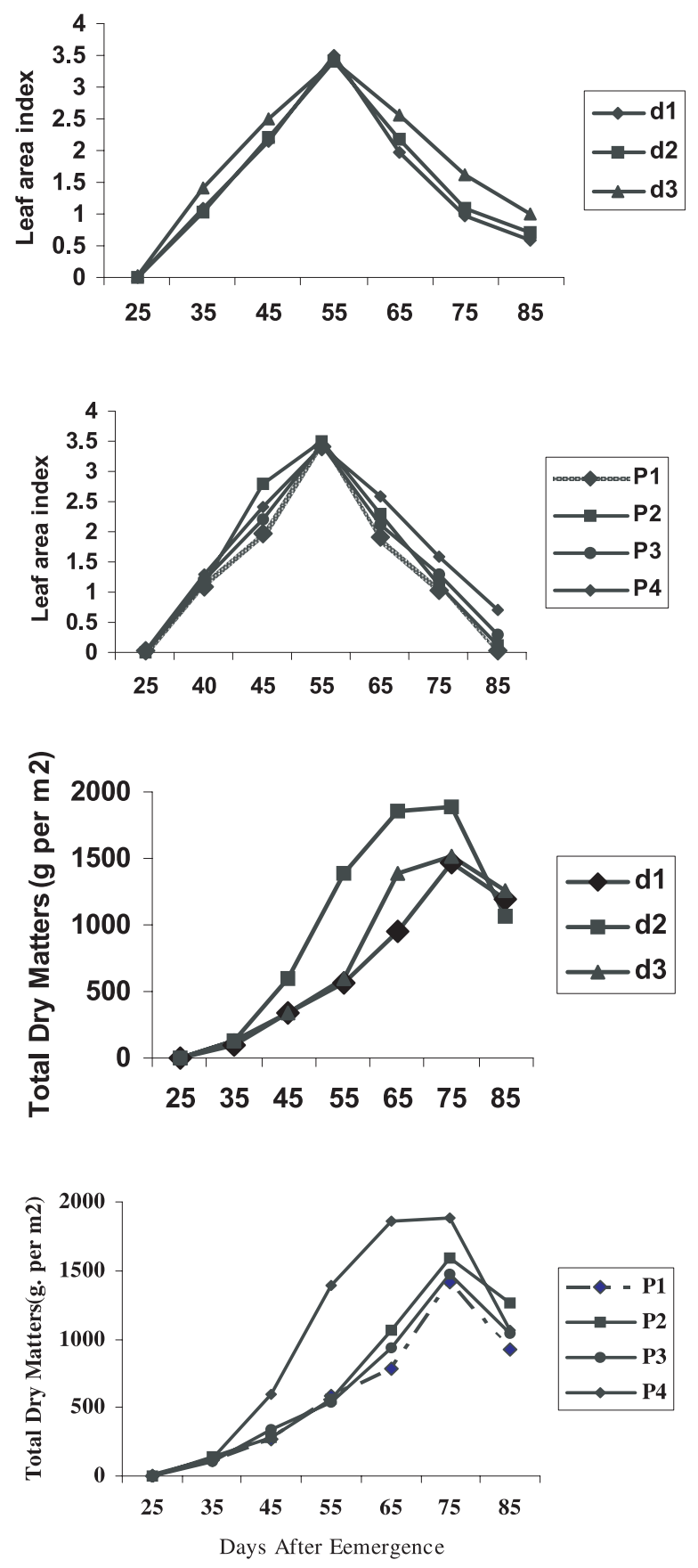

Figure 4. Relationship between leaf area index (LAI) and total dry matter during the vegetative and productive periods for sunflower grown in response to planting patterns and plant densities. L.S.D. $(P<0.05)$. $\mathrm{P}=$ planting patterns; $P_{1}=$ wide rows, $P_{2}=$ conventional rows, $P_{3}=$ twin rectangular rows, $P_{4}=$ twin zigzag rows. $\mathrm{d}=$ planting densities; $\mathrm{d}_{1}=6$ plants $\mathrm{m}^{-2}, \mathrm{~d}_{2}=8$ plants $\mathrm{m}^{-2}, \mathrm{~d}_{3}=10$ plants $\mathrm{m}^{-2}$. Means comparison defined by Duncan's range test at the $5 \%$ level.

rows compared with twin zigzag and conventional rows, while their thousand seed weight was equal at the lower plant density (8 plants $\mathrm{m}^{-2}$ ) (Tab. II). As expected, according to previous
Yield(kg per ha.)

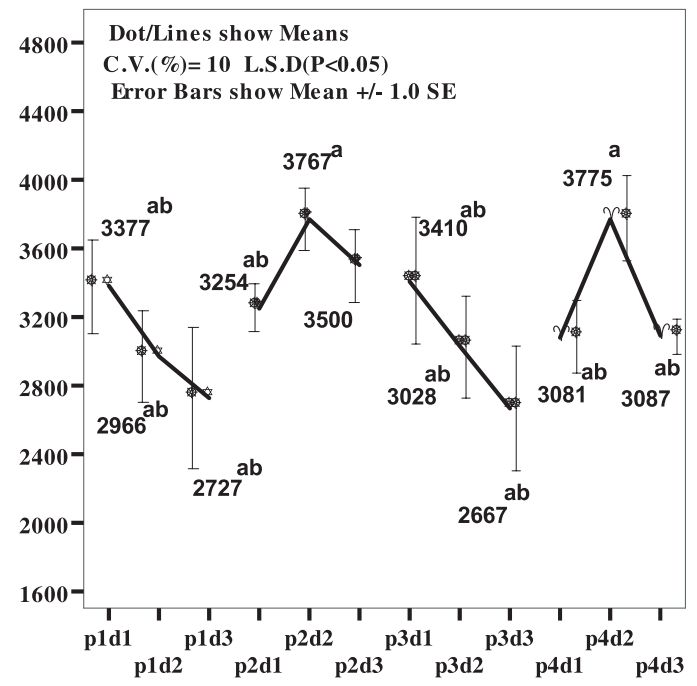

Figure 5. Relationships regarding grain yield increase in response to planting patterns and plant densities. $P=$ planting patterns; $P_{1}=$ wide rows, $P_{2}=$ conventional rows, $P_{3}=$ twin rectangular rows, $P_{4}=$ twin zigzag rows. $d=$ planting densities; $d_{1}=6$ plants $\mathrm{m}^{-2}, \mathrm{~d}_{2}=8$ plants $\mathrm{m}^{-2}, \mathrm{~d}_{3}=10$ plants $\mathrm{m}^{-2}$. Means comparison defined by Duncan's range test at the $5 \%$ level.

studies (Miller et al., 1984; Majid and Schneiter, 1988; Zaffaroni and Schneiter, 1989). Planting patterns had no significant effect $(P<0.05)$ on number of seeds per head (Tab. II). Seed number decreased with increased density of planting. A higher number of seeds was achieved by low density ( 6 plants $\mathrm{m}^{-2}$ ) (Tab. II).

Decreasing the plant-to-plant competition for available water, nutrient and light increases seed weight and seed number per head, but planting sunflower at the minimal population $\left(6\right.$ plants $\left.\mathrm{m}^{-2}\right)$ reduces number of seeds per $\mathrm{m}^{-2}$ (Tab. II). The maximum seed number per $\mathrm{m}^{2}$ was obtained by twin zigzag rows and conventional rows $\times 8$ plants $\mathrm{m}^{2}$ (Tab. II).

Plant densities, Planting patterns and Plant densities $\times$ Planting patterns had a significant effect on yield $(P<0.05)$ (Fig. 5). Yield tended to increase in twin zigzag rows and conventional planting patterns at the rate of 8 plants $\mathrm{m}^{-2}$ (Fig. 5). Other studies demonstrate a high rate of yield when triangular (equidistant) planting patterns are used (Ikeda and Santo, 1992; Miura et al., 1987). The periods bracketing flowering in sunflower (Chimenti and Hall, 1992; Connor and Sadras, 1992; Cantagallo et al., 1997) are times during the crop cycle that are most critical for yield determination. Sunflower yield increase in response to narrow rows is closely related to the improvement in light interception during the critical period for grain set (Andrade et al., 2002). However, this research indicates that despite optimum spatial arrangement of twin zigzag planting patterns, its yield equaled conventional planting patterns. This may refer to the fact that every two rows of plants of this arrangement take up water from one furrow (Fig. 1). Moreover, sunflower has a high capacity to achieve full light interception at flowering, provided that adapted cultivars are grown without serious water deficits or other adversities during the vegetative period (Andrade et al., 2002). 
Table II. Means comparison of defined characters by Duncan's range test at the 5\% level.

\begin{tabular}{|c|c|c|c|c|c|}
\hline Seed oil yield $\left(\mathrm{kg} \mathrm{ha}^{-1}\right)$ & $\begin{array}{l}\text { Seed oil content } \\
(\%)\end{array}$ & No. of seeds $\mathrm{m}^{-2}$ & $\begin{array}{c}\text { No. of } \\
\text { seeds per head }\end{array}$ & $\begin{array}{c}1000 \text { seed weight } \\
(\mathrm{g})\end{array}$ & Treatments \\
\hline & & & & & Planting patterns $(\mathrm{P})$ \\
\hline $47.08^{\mathrm{a}}$ & $47.08^{\mathrm{a}}$ & $4948^{d}$ & $824^{\mathrm{a}}$ & $48.5^{\mathrm{a}}$ & $\mathrm{P}_{1}$ \\
\hline $46.60^{\mathrm{a}}$ & $46.60^{\mathrm{a}}$ & $7001^{\mathrm{a}}$ & $907^{\mathrm{a}}$ & $50.2^{\mathrm{a}}$ & $\mathrm{P}_{2}$ \\
\hline $45.30^{\mathrm{a}}$ & $45.30^{\mathrm{a}}$ & $6065^{\mathrm{c}}$ & $809^{\mathrm{a}}$ & $49.5^{\mathrm{a}}$ & $\mathrm{P}_{3}$ \\
\hline \multirow[t]{2}{*}{$46.32^{\mathrm{a}}$} & $46.32^{\mathrm{a}}$ & $6622^{b}$ & $862^{\mathrm{a}}$ & $49.7^{\mathrm{a}}$ & $\mathrm{p}_{4}$ \\
\hline & & & & & Planting densities (d) \\
\hline $46.75^{\mathrm{ab}}$ & $46.75^{\mathrm{ab}}$ & $6563^{\mathrm{b}}$ & $1094^{\mathrm{a}}$ & $51.7^{\mathrm{a}}$ & $\mathrm{d}_{1}$ \\
\hline $47.00^{\mathrm{a}}$ & $47.00^{\mathrm{a}}$ & $7040^{\mathrm{a}}$ & $880^{\mathrm{b}}$ & $48.8^{\mathrm{b}}$ & $\mathrm{d}_{2}$ \\
\hline $45.23^{\mathrm{b}}$ & $45.23^{b}$ & $5433^{\mathrm{c}}$ & $598^{\mathrm{c}}$ & $47.9^{\mathrm{b}}$ & $\mathrm{d}_{3}$ \\
\hline 5 & 5.05 & 5 & 3 & 10 & C.V $(\%)$ \\
\hline S. & S. & S. & S. & S. & Interaction \\
\hline $1503^{\mathrm{ab}}$ & $47^{\mathrm{ab}}$ & $6768^{e}$ & $1128^{\mathrm{a}}$ & $52^{\mathrm{a}}$ & $\mathrm{p}_{1} \mathrm{~d}_{1}$ \\
\hline $1420^{\mathrm{ab}}$ & $48^{\mathrm{a}}$ & $4806^{\mathrm{i}}$ & $801^{\mathrm{c}}$ & $47^{\mathrm{b}}$ & $\mathrm{p}_{1} \mathrm{~d}_{2}$ \\
\hline $1266^{\mathrm{b}}$ & $45^{\mathrm{ab}}$ & $3270^{\mathrm{k}}$ & $545^{\mathrm{e}}$ & $47^{\mathrm{b}}$ & $\mathrm{p}_{1} \mathrm{~d}_{3}$ \\
\hline $1566^{\mathrm{ab}}$ & $48^{\mathrm{a}}$ & $6504^{\mathrm{f}}$ & $1084^{\mathrm{a}}$ & $52^{\mathrm{a}}$ & $\mathrm{p}_{2} \mathrm{~d}_{1}$ \\
\hline $1775^{\mathrm{a}}$ & $47^{\mathrm{ab}}$ & $7528^{\mathrm{a}}$ & $941^{\mathrm{ab}}$ & $50^{\mathrm{ab}}$ & $\mathrm{p}_{2} \mathrm{~d}_{2}$ \\
\hline $1545^{\mathrm{ab}}$ & $45^{\mathrm{b}}$ & $6970^{\mathrm{c}}$ & $697^{\text {cde }}$ & $49^{\mathrm{ab}}$ & $\mathrm{p}_{2} \mathrm{~d}_{3}$ \\
\hline $1579^{\mathrm{ab}}$ & $46^{\mathrm{ab}}$ & $6816^{\mathrm{d}}$ & $1136^{\mathrm{a}}$ & $53^{\mathrm{a}}$ & $\mathrm{P}_{3} \mathrm{~d}_{1}$ \\
\hline $1416^{\mathrm{ab}}$ & $47^{\mathrm{ab}}$ & $6048^{\mathrm{j}}$ & $756^{\mathrm{bcd}}$ & $49^{\mathrm{ab}}$ & $\mathrm{p}_{3} \mathrm{~d}_{2}$ \\
\hline $1067^{\mathrm{b}}$ & $43^{b}$ & $5330^{\mathrm{i}}$ & $533^{\mathrm{e}}$ & $47^{b}$ & $\mathrm{p}_{3} \mathrm{~d}_{3}$ \\
\hline $1207^{\mathrm{ab}}$ & $46^{\mathrm{ab}}$ & $6162^{\mathrm{g}}$ & $1027^{\mathrm{a}}$ & $51^{\mathrm{a}}$ & $\mathrm{p}_{4} \mathrm{~d}_{1}$ \\
\hline $1759^{\mathrm{a}}$ & $47^{\mathrm{ab}}$ & $7544^{\mathrm{a}}$ & $943^{\mathrm{ab}}$ & $50^{\mathrm{ab}}$ & $\mathrm{p}_{4} \mathrm{~d}_{2}$ \\
\hline $1442^{\mathrm{ab}}$ & $47^{\mathrm{ab}}$ & $6160^{\mathrm{h}}$ & $616^{\text {cde }}$ & $49^{\mathrm{ab}}$ & $\mathrm{p}_{4} \mathrm{~d}_{3}$ \\
\hline
\end{tabular}

Mean seed oil content and seed oil yield showed no significant difference among planting patterns (Tab. II). However, there was a significant difference between seed oil content and seed oil yield in planting densities and planting patterns $\times$ densities of planting (Tab. II). The wide, zigzag and conventional planting patterns $\times 8$ plants $\mathrm{m}^{-2}$ cause higher seed oil yield (Tab. II). Robinson et al. (1980) reported that equidistant planting patterns cause higher yield and seed oil yield in sunflower. Gubbels and Dedio (1990) reported that with increased planting density, seed oil yield was increased.

\section{CONCLUSION}

Equidistant plant distribution produced a higher radiation interception and extinction coefficient. Moreover, when row spacing was reduced, grain yield increased. The greatest increase in radiation interception and in the extinction coefficient in response to planting patterns and plant densities was observed in twin zigzag rows $\times 8$ plants $\mathrm{m}^{-2}$. Twin zigzag rows $\times$ 8 plants $\mathrm{m}^{-2}$ and conventional rows $\times 8$ plants $\mathrm{m}^{-2}$ produced the highest yield.
The greater light interception led to greater suppression of late-emerging weeds; therefore, selection of appropriate planting patterns could be an option for controlling weeds in sustainable agriculture.

Acknowledgment: The research of other scientists has always been enlightening for me, so the author extends thanks to all agricultural scientists.

\section{REFERENCES}

Alessi J., Power J.F., Zlmmerman D.C. (1977) Sunflower yield and water use as influenced by planting date, population and row spacing, Agron. J. 69, 465-469.

Andrade F.H., Calvino P., Cirilo A., Barbieri P. (2002) Yield Responses to narrows Rows Depend on Increased Radiation Interception, Agron J. 94, 975-980.

Board J.E., Harville B.G., Saxton A.M. (1990) Narrow-row seed yield enhancement in determinate soybean, Agron. J. 82, 64-68.

Board J.E. (2004) Soybean Cultivar Differences Light Interception and Leaf Area Index during Seed filing, Agron. J. 96, 305-310. 
Bullock D.G., Nielson R.L., Nyquist W.E. (1988) A growth analysis of corn grown in conventional and equidistant plant spacing, Crop Sci. $28,254-258$.

Cantagallo J.E., Chimenti C.A., Hall A.J. (1997) Number of seeds per unit area in sunflower correlates well with a photothermal quotient, Crop Sci. 37, 1780-1786.

Clegg M.D., Bigges W.W., Eastin J.D., Maranville J.W., Sulvin C.Y. (1974) Light transmission in field communities of sorghum, Agron. J. 66, 471-476.

Chimenti C.A., Hall A.J. (1992) Sensibilidad del número de frutos por capítulo de girasol (Helianthus annuus L.) a cambios en el nivel de radiación durante la ontogenia del cultivo, in: Actas XIX Reunión Argentina de Fisiología Vegetal. Sociedad Argentina de Fisiología Vegetal, Córdoba, Argentina, pp. 27-28.

Connor D.J., Sadras V.O. (1992) Physiology of yield expression in sunflower, Field Crops Res. 30, 333-389.

Duncan W.G. (1986) Planting patterns and soybean yield, Crop Sci. 26, 584-588.

Edwards J.T., Purcell L.C., Vories E.D. (2005) Light interception and yield potential of short season maize (zea mays L.) Hybrids in the Midsouth, Agron. J. 97, 225-234.

Egharevba P.N. (1975) Planting pattern and light interception in maize, in: Proc. Physiology program formulation workshop, Ibadan, Nigeria, April 1975, IITA, Ibadan, Nigeria, pp. 15-17.

Flenet F.J., kiniry R., board J.E., westgate M.E., reicosky D.C. (1996) Row spacing effects on light coefficient of of corn, sorghum, soybean, and sunflower, Agron. J. 88, 185-190.

Graham D.L., Steiner J.L., Wiese A.F. (1988) Light absorption and Cooperation in mis Sorghum - Pig weed communities, Agron. J. 80, 415418.

Gubbels G.H., Dedio W. (1990) Response of early-maturing sunflower hybrids to row spacing and plant density, Can. J. Sci. 70, 11691171.

Ikeda T., Sato K. (1992) Relation between plant density and yield components in soybean plant, Jpn J. Crop Sci. 59, 219-244.

Kareln D.L., Camp C.R. (1985) ROW spacing, plant population, and water management effects on corn in the Atlantic coastal plain, Agron. J. 77, 393-398.

Kiniry J.R., Williams J.R., Gassman P.W., Debaeke P. (1992) A General process-oriented model for two completing plant species, T. ASAE $35,801-810$.

MacGowan M., Taylor H.M., Willingham J. (1991) Influence of row spacing on growth, light and water use by sorghum, J. Agric. Sci. Camb. 116, 329-339.
Majid H.R., Schneiter A.A. (1988) semi dwarf and conventional height sunflower performance at five plant population, Agron. J. 79, 681684.

Mason R.C., Coates D.B., Wilson G.L., Foale M.A. (1982) Growth and productivity of irrigated sorghum bicolor. 1. Moeach in northern Australian: Plant density and arrangement differs on light interception and distribution, and grain yield, in the hybrid Texas 610sr in low and medium latitudes, Aust. J. Agr. Res. 33, 773-784.

Muchow R.C., Sinclair T.R., Bennett J.M. (1990) Temperature and solar radiation effects on potential maize yield across location, Agron. J. $82,338-343$.

Miller B.C., Opilinger E.S., Randm R., Peter J., Wies G. (1984) Effect of planting date and plant population on safflower performance, Agron. J. 79, 681-684.

Miura H., Wijeyathungam K., Gemma T. (1987) Variation in seed yield of soybean as affected by planting patterns, Jpn J. Crop Sci. 56, 652656.

Muchow R.C., Sinclair T.R., Bennet J.M. (1990) Temperature and solar radiation effects on potential maize yield across location, Agron. J. $82,338-342$.

Murphy S.D., Yakubu Y., Weise S.F., Swanton C.J. (1996) Effect of planting pattern and inter - row cultivation on competition between Corn (Zea Mays) and late emerging Weeds, Weed Sci. 44, 865-870.

Nishiiri K. (1976) Studies on the productivity of soybeans in mechanized cultivation, Bull. Tohoku Natl. Agric. Exp. Stn. 54, 91-286.

Parvez A.Q., Gardner F.P., Boote K.J. (1989) Determinate and indeterminate-type soybean cultivar responses to pattern, density and planting date, Crop Sci. 29, 150-157.

Robinson R.G., Ford J.H., Lueschen W.E., Rabas D.L., Smith L.Y., Warens D.D. (1980) Response of sunflower to plant population, Agron. J. 72, 869-871.

Schneiter A., Miller J.F. (1981) Description of solar radiation and dry matter production by various soybean planting patterns, Crop Sci. 21, 901-903.

Sinclair T.R. (1986) Water and nitrogen limitation in soybean grain production: i. Model development, Field Crops Res. 15, 125-141.

Steer B.T., Milory S.P., Kamona R.M. (1993) A model to simulate the development, growth and yield of irrigated sunflower, Field Crops Res. 32, 83-99.

Wiggans R.G. (1939) The influence of space and arrangement on the production of soybean plants, J. Am. Soc. Agron. 31, 314-321.

Wilocox J.R. (1974) Response of three soybean strains to equidistant spacing, Agron. J. 66, 409-412.

Zaffaroni E., Schneiter A.A. (1989) Water use efficiency and light interception of semi dwarf and standard - height sunflower hybrids grown in different row arrangements, Agron. J. 81, 831-836. 